\title{
Parametric Approach for Wheat Production in Egypt and Spain
}

\author{
Yahia Hamid A. Elasraag \\ Lecturer, Department of Agricultural Economics, Faculty of Agriculture, \\ Cairo University, Giza, Egypt.
}

\begin{abstract}
This study has focused on comparison the technical efficiency of wheat production in Egypt and Spain in the time period 1995-2013. The study applies the stochastic frontier approach and the specification of Battese and Coelli (1995) for efficiency measurement. The results indicate that the mean of technical efficiency of wheat production in Egypt higher than Spain.
\end{abstract}

Key words: wheat, stochastic frontier, technical efficiency, Egypt, Spain.

\section{Introduction}

Wheat is one of the most important cereals grown successfully in Egypt. Wheat in Egypt cultivated in the old lands that found in Nile Valley and Delta; and in the new lands that have been reclaimed (Gowayed, 2009). Wheat can be grown all over Spain. In higher areas it is often the only crop possible. Wheat, as well as barley, is mainly grown as a winter crop. Sowing is done in autumn and Northern European spring-wheat varieties may be used for this purpose. In the higher areas of the central plateau, sowing in spring may be preferred because the risk of winter killing (Belderok et al., 2000). Measuring efficiency is the popular approach to understand the performance of farmers in mobilizing their resources in the given technology (Khanal et al., 2012). This paper is organized as follows: the next section deals with the methodology; section 3 indicates the data and results. The final section presents the conclusions.

\section{Methodology}

The Cobb-Douglas production function is an adequate representation for the data. The Cobb-Douglas production function can be defined as:

$$
\ln y_{i t}=\beta_{0}+\sum_{j=1}^{n} \beta_{j} \ln \mathrm{x}_{j i t}+\beta_{t} t+v_{i t}-u_{i t}
$$

where $y_{i t}$ is the wheat production of the $i$-th country at the $t$-th time period; $x_{j i t}$ is the $j$-th input of the $i$-th country at $t$-th time period; $\beta$ is unknown parameter to be estimated; $t$ is the time variable; $v_{i t}$ is a vector of random errors that are assumed to be independently and identically distributed iid $N\left(0, \sigma_{v}^{2}\right)$; and $u_{i t}$ is a one sided $\left(u_{i t} \geq 0\right)$ efficiency component that captures the technical inefficiency of the $i$-th country. The two error components $\left(v_{i t}\right.$ and $\left.u_{i t}\right)$ are independent of each other.

The inefficiency effect model defined by Battese and Coelli (1995) is specified as follows:

$u_{i t}=\delta_{0}+\sum_{j=1}^{n} \delta_{j} Z_{j i t}$

where $u_{i t}$ is the technical inefficiency of the $i$-th country at $t$-th time period; $\delta$ is a vector of parameters to be estimated; and $Z_{j i t}$ is a vector of variables which expected 
to influence the level of technical inefficiency of the $i$-th country at $t$-th time period. This study incorporates the time variable to verify if the technical inefficiency increase or decrease in the analyzed period. The Maximum Likelihood estimates for the parameters of the stochastic frontier model, defined by equations (1) and (2) can be obtained by using the Frontier 4.1 program.

\section{Data and results}

Table 1 shows the production and area of wheat in Egypt and Spain during the time period 1995-2013. In Egypt, the wheat production increased from 5722.44 thousand ton in 1995 to 9460.20 thousand ton in 2013. The annual average percentage growth rate of wheat production for the time period 1995-2013 is $2.83 \%$. The wheat area increased from 1055.38 thousand hectare in 1995 to 1418.71 thousand hectare in 2013. The annual average percentage growth rate of wheat area for the time period $1995-2013$ is $1.66 \%$. In Spain, the wheat production increased from 3138.70 thousand ton in 1995 to 7602.60 thousand ton in 2013. The annual average percentage growth rate of wheat production for the time period 1995-2013 is $5.04 \%$. The wheat area decreased from 2126.40 thousand hectare in 1995 to 2121.90 thousand hectare in 2013. The annual average percentage growth rate of wheat area for the time period $1995-2013$ is $-0.01 \%$.

Table 1. Production and area of wheat in Egypt and Spain (1995-2013).

\begin{tabular}{c|c|c|c|c}
\hline \multicolumn{2}{c|}{ Egypt } & \multicolumn{2}{c}{ Spain } \\
\hline Year & $\begin{array}{c}\text { Wheat Production } \\
\text { (Thousand Ton) }\end{array}$ & $\begin{array}{c}\text { Wheat Area } \\
\text { (Thousand Hectare) }\end{array}$ & $\begin{array}{c}\text { Wheat Production } \\
\text { (Thousand Ton) }\end{array}$ & $\begin{array}{c}\text { Wheat Area } \\
\text { (Thousand Hectare) }\end{array}$ \\
\hline $\mathbf{1 9 9 5}$ & 5722.44 & 1055.38 & 3138.70 & 2126.40 \\
$\mathbf{1 9 9 6}$ & 5735.37 & 1017.19 & 6040.50 & 2012.40 \\
$\mathbf{1 9 9 7}$ & 5849.13 & 1044.59 & 4676.29 & 2078.55 \\
$\mathbf{1 9 9 8}$ & 6093.15 & 1017.28 & 5436.30 & 1912.56 \\
$\mathbf{1 9 9 9}$ & 6346.64 & 999.10 & 5083.80 & 2422.40 \\
$\mathbf{2 0 0 0}$ & 6564.05 & 1034.99 & 7293.62 & 2353.03 \\
$\mathbf{2 0 0 1}$ & 6254.58 & 983.74 & 5007.70 & 2177.01 \\
$\mathbf{2 0 0 2}$ & 6624.87 & 1029.59 & 6822.16 & 2406.64 \\
$\mathbf{2 0 0 3}$ & 6844.69 & 1053.02 & 6290.10 & 2151.50 \\
$\mathbf{2 0 0 4}$ & 7177.86 & 1094.74 & 7096.72 & 2175.03 \\
$\mathbf{2 0 0 5}$ & 8140.96 & 1253.82 & 4026.69 & 2274.11 \\
$\mathbf{2 0 0 6}$ & 8274.23 & 1286.75 & 5521.58 & 1920.23 \\
$\mathbf{2 0 0 7}$ & 7379.00 & 1140.98 & 6436.36 & 1803.31 \\
$\mathbf{2 0 0 8}$ & 7977.05 & 1226.65 & 6714.30 & 2067.00 \\
$\mathbf{2 0 0 9}$ & 8522.10 & 1335.30 & 4804.77 & 1772.75 \\
$\mathbf{2 0 1 0}$ & 7177.40 & 1287.63 & 5941.20 & 1948.07 \\
$\mathbf{2 0 1 1}$ & 8407.13 & 1284.95 & 6876.66 & 1994.65 \\
$\mathbf{2 0 1 2}$ & 8795.48 & 1336.23 & 4650.30 & 1758.90 \\
$\mathbf{2 0 1 3}$ & 9460.20 & 1418.71 & 7602.60 & 2121.90 \\
Mean & 7228.80 & 1152.71 & 5761.07 & 2077.71 \\
Rate & 2.83 & 1.66 & 5.04 & -0.01 \\
\hline $\mathbf{A n g}$ & & & &
\end{tabular}

(a) Annual average percentage growth rate (1995-2013)

Source: FAOSTAT and own elaboration

Table 2 shows the Ordinary Least Squares (OLS) and Maximum Likelihood Estimates (MLE) of the Cobb-Douglas stochastic frontier production function. The coefficient of area is negative and significant at OLS, while it is positive and insignificant at MLE, this may be due to the soil problems. The technical change coefficient is positive and significant at OLS and MLE. This result indicates technical 
progress over time. For the inefficiency effect model, the coefficient of the time variable is positive and insignificant at MLE, indicates that there is no impact from the time variable on the inefficiency of wheat production through the period of study.

Table 2. OLS and MLE of the Cobb-Douglas stochastic frontier production function.

\begin{tabular}{c|c|c|c|c|c|c}
\hline \multirow{2}{*}{ Variable } & \multicolumn{2}{|c|}{ OLS } & \multicolumn{2}{c}{ MLE } & \multicolumn{2}{c}{} \\
\cline { 2 - 6 } & Coefficient & Standard-error & t-ratio & Coefficient & Standard-error & t-ratio \\
\hline Frontier Production Function & & & & & & \\
Constant & 19.9437 & 1.3129 & 15.1901 & 15.6339 & 1.5110 & 10.3467 \\
Area & -0.3005 & 0.0921 & -3.2614 & 0.0182 & 0.1060 & 0.1720 \\
Time & 0.0221 & 0.0053 & 4.1775 & 0.0230 & 0.0101 & 2.0970 \\
Inefficiency Effects & & & & & & \\
Time & & & & 0.0081 & 0.0315 & 0.2586 \\
Sigma-squared & 0.0316 & & & 0.0791 & 0.0153 & 5.2367 \\
Gamma & & & & 0.9999 & 0.0628 & 15.9135 \\
\hline
\end{tabular}

Source: Own elaboration

Table 3 shows the annual levels of technical efficiency of wheat production in Egypt and Spain. The levels of technical efficiency of wheat production in Egypt and Spain make clear improving during the time period 1995-2013. In Egypt the minimum level of technical efficiency is 0.7849 in 2010, while the maximum level of technical efficiency is 0.9995 in 2005 . The mean technical efficiency of the time period 1995-2013 is 0.9005 and the annual average percentage growth rate is 0.4604. In Spain the minimum level of technical efficiency is 0.4805 in 1995 , while the maximum level of technical efficiency is 0.9933 in 2000 . The mean technical efficiency of the time period 1995-2013 is 0.7160 and the annual average percentage growth rate is 2.6461 .

Table 3. Technical efficiency of wheat production in Egypt and Spain (1995-2013).

\begin{tabular}{lcc}
\hline & \multicolumn{2}{c}{ Technical efficiency } \\
\hline Year & Egypt & Spain \\
\hline $\mathbf{1 9 9 5}$ & 0.8873 & 0.4805 \\
$\mathbf{1 9 9 6}$ & 0.8696 & 0.9046 \\
$\mathbf{1 9 9 7}$ & 0.8663 & 0.6839 \\
$\mathbf{1 9 9 8}$ & 0.8823 & 0.7782 \\
$\mathbf{1 9 9 9}$ & 0.8984 & 0.7081 \\
$\mathbf{2 0 0 0}$ & 0.9074 & 0.9933 \\
$\mathbf{2 0 0 1}$ & 0.8457 & 0.6674 \\
$\mathbf{2 0 0 2}$ & 0.8745 & 0.8869 \\
$\mathbf{2 0 0 3}$ & 0.8827 & 0.8007 \\
$\mathbf{2 0 0 4}$ & 0.9040 & 0.8827 \\
$\mathbf{2 0 0 5}$ & 0.9995 & 0.4890 \\
$\mathbf{2 0 0 6}$ & 0.9922 & 0.6573 \\
$\mathbf{2 0 0 7}$ & 0.8666 & 0.7496 \\
$\mathbf{2 0 0 8}$ & 0.9143 & 0.7623 \\
$\mathbf{2 0 0 9}$ & 0.9532 & 0.5346 \\
$\mathbf{2 0 1 0}$ & 0.7849 & 0.6449 \\
$\mathbf{2 0 1 1}$ & 0.8985 & 0.7291 \\
$\mathbf{2 0 1 2}$ & 0.9180 & 0.4829 \\
$\mathbf{2 0 1 3}$ & 0.9638 & 0.7689 \\
Mean $_{\text {Rate }}^{\text {a }}$ & 0.9005 & 0.7160 \\
\hline
\end{tabular}

( $\left.{ }^{(}\right)$Annual average percentage growth rate (1995-2013)

Source: Own elaboration 


\section{Conclusions}

This paper aims to compare the technical efficiency of wheat production in Egypt and Spain during the time period 1995-2013. The data used in this study is a panel data at the level of Egypt and Spain, it represents the time period 1995-2013 and taken from FAOSTAT. The study applies the stochastic frontier approach for efficiency measurement and the Cobb-Douglas production function is used. The specification of Battese and Coelli (1995) is employed. The coefficient of area is negative and significant at OLS, while it is positive and insignificant at MLE. The technical change coefficient is positive and significant at OLS and MLE. For the inefficiency effect model, the coefficient of the time variable is positive and insignificant at MLE, indicates that there is no impact from the time variable on the inefficiency of wheat production through the period of study. The levels of technical efficiency vary among Egypt and Spain. In Egypt the minimum level of technical efficiency is $78.49 \%$ in 2010 , while the maximum level of technical efficiency is $99.95 \%$ in 2005. In Spain the minimum level of technical efficiency is $48.05 \%$ in 1995, while the maximum level of technical efficiency is $99.33 \%$ in 2000 . The study suggests the following recommendations, investigate the soil problems and land quality of wheat production; and improve the technology of wheat production.

\section{References}

Battese, G.E., and Coelli, T.J. (1995). A model for technical inefficiency effects in a stochastic frontier production function for panel data. Empirical Economics 20: 325-332.

Belderok, B., Mesdag, J., and Donner, D.A. (2000). Bread-Making Quality of Wheat: A Century of Breeding in Europe. Springer Science \& Business Media.

Coelli, T.J. (1996). A guide to FRONTIER Version 4.1: A Computer Program for Stochastic Frontier Production and Cost Function Estimation. CEPA Working Paper, No. 7/96, Centre for Efficiency and Productivity Analysis, University of New England, Armidale, Australia.

FAOSTAT (1995-2013). Statistics Division, Food and Agriculture Organization of the United Nations (FAO).

Gowayed, S. (2009). Egyptian Wheat. Doctoral Dissertation. Department of Agrobiodiversity, Institute of Crop Sciences, University of Kassel, Germany.

Khanal, N.P., Maharjan, K.L., Sapkota, A. (2012). Technical efficiency in wheat seed production: A case study from Tarai region of Nepal. Journal of International Development and Cooperation 19 (1): 41-50.

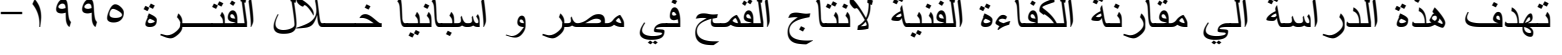
r ا • r . طبقت الدر اسة طريقة [Stochastic frontier [Battese and Coelli (1995) البيانات المستعملة في هذة الدر اسة في صورة panel data و مصدر ها FAOSTAT و تمنت مصر و اسبانيا خلا تل تلك الفتزة

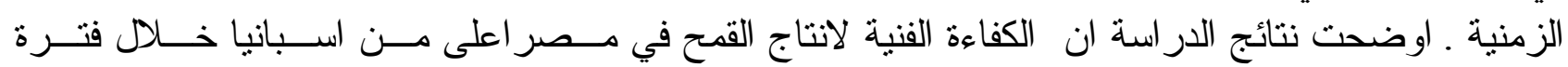

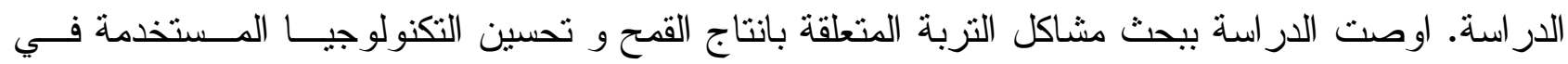

